\title{
ANALISIS DESKRIPTIF MOTIVASI KERJA PEGAWAI
}

\author{
(Studi pada salah satu instansi PEMDA di Kota Cimahi)
}

\author{
Mia Nursanty ${ }^{1}$, M. Sidik Priadana ${ }^{2}$ \\ PEMDA Kota Cimahi ${ }^{1}$ \\ Universitas Pasudan, Bandung ${ }^{2}$ \\ Email: mianursanty@gmail.com ${ }^{1}$, msidik.priadana@gmail.com²
}

\begin{abstract}
Work motivation can be a driving force for someone to carry out an activity to get the best results; there needs to be a solid push to increase individual motivation. Departing from the critical role of work motivation, the researcher intends to research employee work motivation. The goal is to get an overview of employee work motivation at one of the local government agencies in Cimahi City. Based on the aims and objectives of the study, the researcher used a descriptive approach to describe employees' work motivation. Respondents who are uses as samples are employees who one of the local government agencies as many as 114 employees. The results of the study illustrate that the study resultss' work motivation is in the good enough to good category. The study results indicate that the condition of employee motivation is adequate; however, it needs to be improved by the leadership of the local agency to achieve optimal employee motivation.
\end{abstract}

Keywords: work motivation, descriptive analysis, local government agencies.

\begin{abstract}
Abstrak
Motivasi dapat menjadi pendorong seseorang melaksanakan suatu kegiatan untuk mendapatkan hasil yang terbaik untuk itu perlu adanya dorongan yang kuat untuk meningkatkan motivasi individu. Berangkat dari peran penting motivasi kerja maka peneliti bermaksud untuk melakukan penelitian mengenai motivasi kerja pegawai. Tujuan yang ingin dicapai yaitu untuk mendapatkan gambaran motivasi kerja pegawai pada salah satu instansi pemerintah daerah di Kota Cimahi. Berdasarkan pada maksud dan tujuan penelitian maka pendekatan deskriptif peneliti gunakan untuk menggambarkan motivasi kerja pegawai. Responden yang
\end{abstract}

Bisnis Dan Iptek | Sekolah Tinggi Ilmu Ekonomi Pasundan Bandung 
dijadikan sample adalah pegawai yang bekerja pada salah satu instansi pemerintah daerah sebanyak 114 orang pegawai. Hasil penelitian menggambarkan bahwa kondisi motivasi kerja pegawai berada pada kategori cukup baik menuju baik. Hasil penelitian mengindikasikan bahwa kondisi motivasi kerja pegawai sudah memadai namun demikian perlu ditingkatkan oleh pimpinan instansi setempat untuk mencapai motivasi kerja pegawai yang optimal.

\section{Kata kunci: motivasi kerja, analisis deskriptif, instansi pemerintah daerah.}

\section{PENDAHULUAN}

Sumber Daya Manusia merupakan salah satu sasaran reformasi Birokrasi, selain tata kelembagaan dan ketatalaksanaan organisasi. (Berman, 2015) Sumber Daya Manusia merupakan motor penggerak dari suatu unit kerja instansi yang sangat berperan dalam meningkatkan produktivitas atau kinerja suatu unit kerja instansi secara keseluruhan. (Knies, Boselie, Gould-Williams \& Vandenabeele, 2017) Organisasi sebagai suatu sistem terbuka berada dalam sebuah lingkungan. Perubahan-perubahan yang terjadi di lingkungan organisasi memerlukan perhatian dari manajer karena bisa memberikan dampak yang besar bagi perkembangan organisasi. Kegiatan organisasi akan merubah lingkungan, dan juga sebaliknya, lingkungan akan mendorong perubahan pada organisasi, begitu juga pengaruhnya dengan iklim organisasi yang tercipta dalam interaksi antar personil yang terlibat di dalamnya. (McCourt, 2006) Organisasi memandang pentingnya pengembangan sumber daya manusia sebab pada saat ini karyawan merupakan asset yang sangat penting dalam pencapaian tujuan organisasi.

Salah satu cakupan Reformasi Birokrasi adalah untuk menciptakan kualitas SDM yang memiliki integritas tinggi dalam bekerja dengan menjunjung tinggi sikap profesionalisme dan nilai-nilai moralitas yang kental dengan kejujuran, kesetiaan, komitmen, serta menjaga keutuhan pribadi. (Turner, Prasojo \& Sumarwono, 2019) Sehingga diharapkan mampu menciptakan kader bangsa dengan SDM yang memiliki produktivitas tinggi dan bertanggungjawab terhadap amanah pekerjaan yang diterima.

Hal-hal yang perlu disadari pemberdayaan aparatur tidak lepas dari faktor - faktor seperti motivasi kerja. Motivasi dapat menjadi pendorong seseorang melaksanakan suatu kegiatan untuk mendapatkan hasil yang terbaik sehingga tidak heran apabila motivasi kerja pegawai tinggi menghasilkan kinerja yang tinggi pula. Seperti yang kita ketahui salah satu bentuk dari motivasi orang bekerja adalah untuk memenuhi kebutuhan ekonomis diantaranya gaji dan tambahan penghasilan karena menentukan tingkat kelayakan hidup pegawai, diharapkan jika memiliki tingkat kehidupan yang layak maka pegawai akan dapat 
tenang melaksanakan pekerjaannya, berdasarkan kebutuhan tersebutlah pegawai mau mengorbankan waktu, tenaga dan pikirannya. (Ciobanu, Androniceanu \& Lazaroiu, 2019)

Tapi perlu juga diingat bahwa kebutuhan ekonomis bukanlah satu-satunya faktor yang memotivasi seseorang untuk menghasilkan kinerja yang baik, faktor yang lainnya yaitu adanya kesempatan untuk berkembang lebih tinggi bagi pegawai. (Beltrán-Martín \& Bou-Llusar, 2018; Sidharta, 2018) Pegawai yang mempunyai motivasi yang baik akan jenuh bila hanya diberi pekerjaan yang monoton, atau kurangnya penghargaan terhadap kinerja pegawai dapat mengurangi semangat pegawai untuk bekerja melampaui standar yang telah ditentukan, tanpa ada keinginan untuk berbuat yang terbaik atau pegawai hanya mau mengerjakan tugas tambahan bila ada perintah atasan tanpa ada inisiatif untuk mengerjakannya.

Motivasi yang kurang kuat dari pegawai terlihat dari bermalas-malasan dalam melaksanakan pekerjaan sehingga melampaui batas waktu yang telah ditentukan, kurang informatif, kurang konsisten, kurang tahu dan kurang menyadari tugas dan fungsinya sehingga sering menimbulkan ketimpangan - ketimpangan dalam menjalankan tugasnya. Dari data dilapangan diketahui bahwa rata-rata kehadiran pegawai masih di atas $80 \%$. Namun demikian yang perlu disikapi adalah prosentase kehadiran minimal masih ada yang $5 \%$. Kesenjangan inilah yang memerlukan perhatian khusus, bahwa masih ada pegawai yang prosentase kehadirannya sangat kecil. Berdasarkan analisa, dari tingkat kehadiran di atas secara lebih rinci, pegawai yang memiliki presentasi terendah justru pegawai yang berusia muda (25 -30 tahun).

Berdasarkan fenomena yang terjadai, maka peneliti melakukan penelitian mengenai motivasi kerja, secara spesifik penelitian ini bertujuan untuk mengetahui, mengkaji dan menganalisis masalah motivasi kerja. Hasil penelitian diharapkan dapat memberikan kontribusi pemikiran terhadap masalah - masalah yang berhubungan dengan sumber daya manusia. Dapat memberikan gambaran bagi pimpinan dalam menentukan kebijakan terutama pada saat pengambilan keputusan dalam rangka meningkatkan kinerja pegawai.

\section{METODE PENELITIAN}

Penelitian dilakukan di salah satu instansi pemerintahan daerah di Kota Cimahi, sedangkan alasan pemilihan tempat penelitian ini didasarkan sebagaimana atas pemikiran dan kondisi yang telah diutarakan dalam latar belakang penelitian. Dalam penelitian ini yang menjadi sample untuk penelitian adalah pegawai sebanyak 114 orang. Metode penelitian deskriptif digunakan untuk 
menggambarkan kondisi motivasi kerja yang didasarkan pada landasan teori motivasi McClleland (Suryadana \& Sidharta, 2019) yang terdiri dari 3 dimensi yaitu

Kebutuhan akan prestasi, Kebutuhan akan kekuasaan dan Kebutuhan akan berafiliasi. Dengan indicator sebagai berikut: Penyelesaian pekerjaan, Hasil pekerjaan yang terbaik, Pengakuan dari pimpinan, Pengakuan dari teman sejawat, Berusaha untuk meningkatkan kemampuan diri, Selalu melakukan perubahan atau inovasi terbaik, Kepuasan akan pekerjaannya, Berinteraksi dengan orang lain dan Bersifat social

Teknik analisis yang digunakan adalah teknik deskriptif. Teknik deskriptif digunakan untuk mendiskripsikan variabel Motivasi kerja. Langkah-langkah yang dilakukan dalam penelitian ini adalah sebagai berikut:

a) Setiap indikator yang dinilai oleh responden, diklasifikasikan dalam lima alternative jawaban dengan menggunakan skala ordinal yang menggambarkan peringkat jawaban.

b) Dihitung total skor setiap variabel/subvariabel $=$ jumlah skor dari seluruh indikator variabel untuk semua responden.

c) Dihitung skor setiap variabel/subvariabel = rata-rata dari total skor.

d) Untuk mendeskripsikan jawaban responden, juga digunakan statistic deskriptif seperti distribusi frekuensi dan tampilan dalam bentuk table ataupun grafik.

e) Untuk menjawab deskripsi tentang masing-masing variabel penelitian ini, digunakan rentang kriteria penilaian sebagai berikut:

$$
\mathbf{R S}=\frac{\mathbf{N}(\mathbf{m}-\mathbf{1})}{\mathbf{m}}
$$

Keterangan:

$\mathrm{n}=$ jumlah sampel yang diambil

$\mathrm{m}=$ jumlah alternative jawaban pada tiap item

Untuk menetapkan peringkat dalam setiap variabel penelitian, dapat dilihat dari perbandingan antara skor aktual dan ideal. Skor aktual diperoleh melalui hasil perhitungan seluruh pendapat responden, sedangkan skor ideal diperoleh dari prediksi nilai tertinggi dikalikan dengan jumlah pertanyaan kuesioner dikalikan dengan jumlah responden. 


\section{October , 2020}

\section{HASIL DAN PEMBAHASAN}

Hasil penelitian terhadap motivasi kerja, dilakukan melalui hasil perhitungan terhadap masing-masing pernyataan sebagai tersaji pada table 1 berikut ini:

Tabel 1. Rekapitulasi Hasil Pernyataan mengenai Motivasi Kerja

\begin{tabular}{|l|c|c|c|c|c|c|c|c|}
\hline \multicolumn{1}{|c|}{ Pernyataan } & \multicolumn{5}{|c|}{ Frekuensi Pernyataan } & TS & Mean & Kriteria \\
\cline { 2 - 9 } & $\mathbf{5}$ & $\mathbf{4}$ & $\mathbf{3}$ & $\mathbf{2}$ & $\mathbf{1}$ & & & \\
\hline $\begin{array}{l}\text { Pegawai akan } \\
\text { termotivasi bila } \\
\text { kebijakan } \\
\text { administrasi tidak } \\
\text { kaku }\end{array}$ & 42 & 31 & 24 & 10 & 7 & 433 & 3,80 & Baik \\
\hline $\begin{array}{l}\text { Setiap kebijakan } \\
\text { pimpinan } \\
\text { senantiasa } \\
\text { mempengaruhi } \\
\text { motivasi pegawai }\end{array}$ & 42 & 17 & 25 & 28 & 2 & 411 & 3,61 & Baik \\
\hline $\begin{array}{l}\text { Pegawai senantiasa } \\
\text { termotivasi untuk } \\
\text { mencapai prestasi } \\
\text { kerja. }\end{array}$ & 68 & 13 & 25 & 2 & 6 & 477 & 4,18 & Baik \\
\hline $\begin{array}{l}\text { Kendali dan } \\
\text { pengawasan yang } \\
\text { baik dan adil dari } \\
\text { pimpinan, akan } \\
\text { memotivasi pegawai }\end{array}$ & 29 & 18 & 49 & 12 & 6 & 394 & 3,46 & Baik \\
\hline $\begin{array}{l}\text { Hubungan yang } \\
\text { baik dengan atasan } \\
\text { akan memotivasi } \\
\text { pegawai }\end{array}$ & 40 & 24 & 16 & 32 & 2 & 410 & 3,60 & Baik \\
\hline $\begin{array}{l}\text { Saya bersedia untuk } \\
\text { menjalin hubungan } \\
\text { kerja dan bekerja } \\
\text { sama dengan pihak } \\
\text { lain dalam rangka } \\
\text { menyelesaikan } \\
\text { tugas-tugas sesuai } \\
\text { dengan fungsinya. }\end{array}$ & 58 & 23 & 21 & 7 & 5 & 464 & 4,07 & Baik \\
\hline $\begin{array}{l}\text { Gaji yang besar } \\
\text { adalah salah satu } \\
\text { motivasi pegawai. }\end{array}$ & 32 & 43 & 26 & 12 & 1 & 435 & 3,82 & Baik \\
\hline $\begin{array}{l}\text { Pegawai merasa } \\
\text { senang, bila } \\
\text { keberadaannya } \\
\text { diakui di tempat } \\
\text { kerja. }\end{array}$ & 59 & 7 & 35 & 9 & 4 & 450 & 3,95 & Baik \\
\hline $\begin{array}{l}\text { Kondisi kerja yang } \\
\text { nyaman dan } \\
\text { kondusif akan } \\
\text { membuat semangat } \\
\text { dalam bekerja } \\
\text { pegawai. }\end{array}$ & 67 & 18 & 16 & 12 & 1 & 480 & 4,21 & Bangat \\
\hline $\begin{array}{l}\text { Kondisi kerja yang } \\
\text { nyaman dan } \\
\text { kondusif akan } \\
\text { membuat semangat } \\
\text { dalam bekerja }\end{array}$ & 43 & 22 & 6 & 41 & 2 & 405 & 3,55 & Baik \\
\hline
\end{tabular}

Bisnis Dan Iptek | Sekolah Tinggi Ilmu Ekonomi Pasundan Bandung 
October , 2020

\begin{tabular}{|c|c|c|c|c|c|c|c|c|}
\hline \multirow{2}{*}{ Pernyataan } & \multicolumn{5}{|c|}{ Frekuensi Pernyataan } & \multirow{2}{*}{ TS } & \multirow{2}{*}{ Mean } & \multirow{2}{*}{ Kriteria } \\
\hline & 5 & 4 & 3 & 2 & 1 & & & \\
\hline \multicolumn{9}{|l|}{ pegawai. } \\
\hline $\begin{array}{l}\text { Pencapaian karir } \\
\text { yang tinggi adalah } \\
\text { motivasi pegawai. }\end{array}$ & 33 & 14 & 13 & 45 & 9 & 359 & 3,15 & $\begin{array}{c}\text { Cukup } \\
\text { Baik }\end{array}$ \\
\hline $\begin{array}{l}\text { Meski tak ada } \\
\text { pimpinan di kantor, } \\
\text { pegawai tetap } \\
\text { semangat untuk } \\
\text { melaksanakan } \\
\text { tugas }\end{array}$ & 30 & 28 & 31 & 23 & 2 & 403 & 3,54 & Baik \\
\hline $\begin{array}{l}\text { Pegawai selalu } \\
\text { termotivasi untuk } \\
\text { maju dan } \\
\text { berkembang. }\end{array}$ & 43 & 49 & 20 & 1 & 1 & 474 & 4,16 & Baik \\
\hline $\begin{array}{l}\text { Prestasi kerja yang } \\
\text { baik akan } \\
\text { memberikan } \\
\text { kepuasan dalam } \\
\text { bekerja }\end{array}$ & 37 & 51 & 10 & 15 & 1 & 450 & 3,95 & Baik \\
\hline $\begin{array}{l}\text { Pegawai akan lebih } \\
\text { termotivasi, bila gaji } \\
\text { dinaikkan. }\end{array}$ & 46 & 18 & 24 & 24 & 2 & 424 & 3,72 & Baik \\
\hline $\begin{array}{l}\text { Bila ada kepedulian } \\
\text { terhadap } \\
\text { permasalahan } \\
\text { kehidupan } \\
\text { pribadi,pegawai } \\
\text { akan lebih } \\
\text { termotivasi. }\end{array}$ & 43 & 38 & 22 & 8 & 3 & 452 & 3,96 & Baik \\
\hline $\begin{array}{l}\text { Dalam bekerja, } \\
\text { pegawai } \\
\text { berkeinginan untuk } \\
\text { memperoleh } \\
\text { prestasi kerja. }\end{array}$ & 22 & 12 & 50 & 23 & 7 & 361 & 3,17 & $\begin{array}{c}\text { Cukup } \\
\text { Baik }\end{array}$ \\
\hline $\begin{array}{l}\text { TOTAL SKOR } \\
\text { PERSENTASE }\end{array}$ & $\begin{array}{c}734 \\
37,87\end{array}$ & $\begin{array}{c}426 \\
21,98\end{array}$ & $\begin{array}{c}413 \\
21,31\end{array}$ & $\begin{array}{c}304 \\
15,69\end{array}$ & $\begin{array}{c}61 \\
3,15\end{array}$ & $\begin{array}{c}1938 \\
100\end{array}$ & & 76 \\
\hline $\begin{array}{l}\text { PERSENI ASE } \\
\text { STDEV }\end{array}$ & & & & $\frac{1}{1,05}$ & & & 3,28 & 4,23 \\
\hline KRITERIA & & & & 8 & & gat & & \\
\hline
\end{tabular}

Sumber: Di olah peneliti.

Berdasarkan tabel distribusi frekuensi diatas, dapat disimpulkan bahwa 17 pernyataan dengan rincian frekuensi menunjukkan jumlah item jawaban responden yang dinyatakan bahwa yang menjawab skala 1 sebesar 3,15\%, menjawab skala 2 sebesar $15,69 \%$, menjawab skala 3 sebesar $21,31 \%$, menjawab skala 4 sebesar $21,98 \%$, dan menjawab skala 5 sebesar $37,87 \%$. Hal ini berarti bahwa data tersebut terpencar dari terkecil sampai terbesar dengan nilai rata-rata sebesar 3,76 dan total skor keseluruhan sebesar 5157 dan standar deviasi sebesar 0,473 dengan kategori jawaban berada pada rentang 3,28 - 4,23 dengan kriteria Cukup Baik menuju Sangat Baik. 
Urutan nilai rata-rata jawaban untuk masing masing pernyataan diurutkan berdasarkan nilai rata-rata terendah yaitu pada pernyataan: Pencapaian Karir yang Tinggi Adalah Motivasi Pegawai dengan nilai rata-rata sebesar 3,15, dan nilai rata-rata terendah kedua yaitu pada pernyataan: Dalam bekerja, pegawai berkeinginan untuk memperoleh prestasi kerja dengan nilai rata-rata sebesar 3,17.

Adapun pernyataan tertinggi adalah pada pernyataan: Kondisi Kerja yang Nyaman dan Kondusif akan Membuat Semangat Dalam Bekerja Pegawai dengan nilai ratarata sebesar 4,21.

Berdasarkan hasil pengolahan data deskriptif dapat disimpulkan jumlah item jawaban responden yang dinyatakan bahwa yang menjawab skala 1 sebesar $3,15 \%$, menjawab skala 2 sebesar 15,69\%, menjawab skala 3 sebesar 21,31\%, menjawab skala 4 sebesar 21,98\%, dan menjawab skala 5 sebesar 37,87 \%. Hal ini berarti bahwa data tersebut terpencar dari terkecil sampai terbesar dengan nilai rata-rata sebesar 3,76 dan total skor keseluruhan sebesar 5157 dan standar deviasi sebesar 0,473 dengan kategori jawaban berada pada rentang 3,28-4,23 dengan kriteria Cukup Baik Menuju Sangat Baik.

Landasan teori yang digunakan dalam penelitian ini ialah teori dari Clelland (Suryadana \& Sidharta, 2019). McClelland mengatakan bahwa ada tiga kebutuhan manusia, yaitu:

a) Kebutuhan berprestasi (need for achievement), yaitu keinginan untuk melakukan sesuatu lebih baik dibandingkan sebelumnya.

b) Kebutuhan untuk berkuasa (need for power), yaitu kebutuhan untuk lebih kuat, lebih berpengaruh terhadap orang lain.

c) Kebutuhan afiliasi (need for afiliation), yaitu kebutuhan untuk disukai, mengembangkan, atau memelihara persahabatan dengan orang lain.

Urutan nilai rata-rata jawaban untuk masing masing pernyataan diurutkan berdasarkan nilai rata-rata terendah yaitu pada pernyataan: Pencapaian karir yang tinggi adalah motivasi pegawai.

Fenomena yang terjadi di lingkungan tempat kerja, mayoritas motivasi pegawai bekerja masih sebatas untuk memenuhi kebutuhan hidup yang masih bersifat kebutuhan fisik dimana pegawai bekerja semata-mata hanyalah untuk mendapatkan penghasilan yang dapat menopang kehidupan mereka dalam segi finansial dan belum sepenuhnya bekerja dengan motivasi untuk untuk meraih karir yang tinggi dalam bekerja. Dengan nilai rata-rata sebesar 3,15, dan nilai ratarata terendah kedua yaitu pada pernyataan: Dalam bekerja, pegawai berkeinginan untuk memperoleh prestasi kerja dengan nilai rata-rata sebesar 3,17. 
Fenomena yang terjadi di lingkungan tempat kerja dimana pegawai bekerja masih sebatas hanya melaksanakan tanggung jawab mereka pada pekerjaan saja dan belum sepenuhnya memiliki motivasi bekerja untuk memperoleh prestasi kerja yang tinggi dalam karir mereka.

Adapun pernyataan tertinggi adalah pada pernyataan: Kondisi Kerja yang Nyaman dan Kondusif akan Membuat Semangat Dalam Bekerja Pegawai dengan nilai ratarata sebesar 4,21.

Fenomena di lingkungan tempat bekerja terasa nyaman dan kondusif dimana hal tersebut membuat semangat pegawai dalam bekerja hal ini terbentuk karena setiap pegawai memiliki hubungan yang harmonis baik dengan rekan kerja maupun dengan staff pimpinan hal ini yang membuat kondisi kerja menjadi nyaman dan kondusif yang memotivasi pegawai untuk giat dalam bekerja. Hasil penelitian menggambarkan bahwa motivasi kerja pegawai sudah memadai, hasil penelitian ini sesuai dengan penelitian yang dilakukan oleh peneliti terdahulu yang membuktikan peran penting motivasi kerja di oraganisasi seperti McCourt (2006); Knies, Boselie, Gould-Williams \& Vandenabeele (2017); Ciobanu, Androniceanu \& Lazaroiu (2019); dan Beltrán-Martín \& Bou-Llusar (2018).

\section{KESIMPULAN}

Berdasarkan hasil pembahasan disimpulkan bahwa gambaran motivasi secara keseluruhan dapat digambarkan cukup baik menuju sangat baik. Namun demikian masih terdapat pernyataan dengan nilai rata-rata terendah yaitu pada pernyataan: Pencapaian karir yang tinggi belum menjadi motivasi utama para pegawai dan aspek terlemah kedua yaitu pada pernyataan: Dalam bekerja, pegawai belum optimal dalam mencapai prestasi kerja. Untuk itu kepala harus dapat menjaga dan mempertahankan motivasi yang sudah ada namun harus diingat ada hal-hal yang masih perlu ditingkatkan dalam motivasi pegawai dimana pegawai harus ditingkatkan motivasinya terutama dalam hal tujuan mereka bekerja dimana pegawai harus dirangsang agar termotivasi untuk mencapai karir yang tinggi dalam pekerjaan mereka. Begitu juga dalam bekerja pegawai harus ditingkatkan motivasinya agar para pegawai senantiasa termotivasi untuk mencapai prestasi kerja yang tinggi.

\section{REFERENSI}

Beltrán-Martín, I., \& Bou-Llusar, J. C. (2018). Examining the intermediate role of employee abilities, motivation and opportunities to participate in the 
October , 2020

relationship between $\mathrm{HR}$ bundles and employee performance. $B R Q$ Business Research Quarterly, 21(2), 99-110.

Berman, E. M. (2015). HRM in development: Lessons and frontiers. Public Administration and Development, 35(2), 113-127.

Ciobanu, A., Androniceanu, A., \& Lazaroiu, G. (2019). An integrated psychosociological perspective on public employees' motivation and performance. Frontiers in Psychology, 10, 36.

Knies, E., Boselie, P., Gould-Williams, J., \& Vandenabeele, W. (2017). Strategic human resource management and public sector performance: context matters. The International Journal of Human Resource Management, DOI: 10.1080/09585192.2017.1407088

McCourt, W. (2006). Conclusion: Improving HRM in Developing Country Governance. In The Human Factor in Governance (pp. 204-230). Palgrave Macmillan, London.

Sidharta, I. (2018). Validation on Utrecht Work Engagement Scale: Multisample and Multi Sectors Analysis. Kontigensi: Jurnal Ilmiah Manajemen, 6(2), 49-58.

Suryadana, M. L., \& Sidharta, I. (2019). MANAJEMEN SUMBER DAYA MANUSIA INDUSTRI HOSPITALITY: Diandra Kreatif. Yogyakarta: Diandra Kreatif.

Turner, M., Prasojo, E., \& Sumarwono, R. (2019). The challenge of reforming big bureaucracy in Indonesia. Policy Studies, 1-19. 